\title{
Plague discourse, quarantine and plague control in early modern England: 1578-1625
}

\author{
ÁKOS TUSSAY* (1)
}

Research Institute of Politics and Government, Eötvös József Research Centre, University of Public Service, Budapest, Hungary

\section{ORIGINAL RESEARCH PAPER}

Received: May 04, 2020 • Revised manuscript received: October 15, 2020 • Accepted: October 28, 2020

Published online: June 8, 2021

(C) 2020 The Author(s)

\begin{abstract}
Plague was a frequent visitor to early modern England, ravishing the whole country six times between 1563 and 1666. The plague problem was, however, definitely not just an English peculiarity. Plague, due to its recurrent and devastating outbreaks, was one of the central themes of late sixteenth-century medical scholarship and social policymaking. Plague was regulated mainly at the local levels, but most of the continental regulations and contemporary guidance seems to endorse two common features. They placed considerable emphasis on contagion and drew certain correlations between contacting plague and poverty on the one hand and meagre living conditions on the other hand. In some desperate attempts, the Elizabethan and Jacobean governments, set out to contain the spread of the disease, missing some marked features of these novel continental practices, issued various ill-suited regulations which dominated English plague control from 1578 to 1666 . Despite these regulations' remarkably egalitarian overtone and seemingly charitable resolutions, this paper argues that the Elizabethan and Jacobean policies of plague control were destined to failure chiefly because of their elitist and inconsiderate measures, reducing them effectively to a harsh policy of confinement of the infected poor masses, taking almost no account of their health or well-being.
\end{abstract}

\section{KEYWORDS}

plague control, quarantine, Thomas Lodge, early modern England, epidemic

\footnotetext{
*Corresponding author. E-mail: Tussay.Akos@uni-nke.hu

${ }^{a}$ The article was funded by the fellowship grant of Eötvös József Research Centre of the University of Public Service.
} 


\section{INTRODUCTION}

On $30^{\text {th }}$ January 2020, the Director General of the World Health Organization declared a public health emergency of international concern over the global outbreak of a novel coronavirus, COVID-19. ${ }^{1}$ COVID-19 is an infectious respiratory illness, spread primarily through droplets of saliva or discharge from the nose when an infected person coughs or sneezes. Most people infected with the virus experience mild to moderate symptoms and recover without requiring special treatment. The elderly and those with underlying medical problems are likely to develop serious illness with a yet uncertain rate of eventual mortality. In a quest to slow down the spreading of the disease governments throughout the world have introduced a variety of regulations from several forms of social distancing to provisional quarantine. These measures have turned the whole world upside down, starting global social and economic crises beyond reckoning.

Nevertheless, despite the personal and communal hardships, people seem to generally obey their governments and follow the respective regulations. What is more, preliminary research suggests that most people do comply with these newly introduced sanitary regulations voluntarily, being, especially those living in urban areas, 'strongly opinionated that serious protective measures are needed'. ${ }^{2}$ One may wonder, however, why is coordinated social distancing working now, when it has failed so many times before? ${ }^{3}$

Of course, there is absolutely no intelligible answer to the proposed question. The different epidemiological, societal, legal, and political contexts mean that one simply cannot seriously compare the motivations of individual and governmental actions of nowadays and the Spanish-flu pandemic, or the Black Death. Nonetheless, comparative analysis of past epidemics of relatively similar circumstances may contribute to an overall understanding of socio-political conduct and legal obligations in emergency situations, especially with a view to quarantine regulations and popular concerns related to such policies of isolation. Now, the successive English plague epidemics between 1563 and 1636 were in many respects similar cases e.g., plague had no effective treatment, it was believed to be transmissible by touch and air and it had grave social and economic effects, and hence is a subject worthy of analysis.

\section{THE PLAGUE-PROBLEM IN EARLY MODERN ENGLAND}

Outbreaks of plague and other pestilences were quite common in medieval and early modern Europe given the relatively low level of medical consciousness, personal and communal hygiene and the lack of proper sanitation. Due to its epidemiological characteristics and the psychological distress and terror accompanying its visitations, ${ }^{4}$ plague was, nevertheless, considerably

\footnotetext{
${ }^{1}$ WHO Director-General's statement on IHR Emergency Committee on Novel Coronavirus (2019- $n$ CoV).

${ }^{2}$ Qazi et al. (2020).

${ }^{3}$ Though some modest results were achieved in some U.S. cities during the Spanish-flu pandemic. See: Bootsma and Ferguson (2007) 7588-93.
}

${ }^{4}$ See: Cohn (2010) 264-91. 
more dreaded than other contagious disease of the time. Paul Slack remarks that there was something very puzzling about the peculiar combination of predictable and unpredictable elements in plague's spreading.

[I]t did move in what were, in the end, predictable directions: from ports to other cities, from cities to surrounding villages, from one house to another', yet 'it missed some towns in its transit along major highways, some houses in its movement along a street, some individuals in its progress throughout a household. ${ }^{5}$

Since there were neither effective remedies nor any kind of rationale for its contagion, plague was, from early on, believed to be simply 'a divine scourge, a retribution for the sins of mankind'. However, from the second half of the sixteenth century, empirical medical knowledge grew steadily with physicians tended to draw seemingly well-founded correlations between poor diet and meagre living conditions and the likelihood of contacting plague. ${ }^{7}$ It is not surprising therefore that contemporary governments endeavoured to handle the issue au fond by incorporating their respective plague controlling measures into their more general framework of social policy. Nonetheless, being a contagious disease, plague's impact went far beyond its effects on public health and demography, effecting, above all, both domestic and international trade and economics in general, urban developments, religion and politics at large. In early modern England, plague was, thus, a considerable factor government had to reckon with. Moreover, two of the severest outbreaks of the era coincided with the accession of the first two Stuart monarchs, giving rise to the popular belief that 'great Plagues come in with King's reigns'.

In this paper, after providing a brief overview of late sixteenth- and early seventeenthcentury plague epidemiology and medicine, I consider the successive plague-regulations from Elizabethan and Jacobean England, arguing that early modern English plague control was to a great extent governed by that prominently emerging late sixteenth-century leitmotif which deemed plague to be chiefly a social problem, bred by poverty. Unlike the other social problems associated with poverty, such as starvation or vagrancy, plague had, however, a direct and dire effect on the upper classes of society as well, since, though plague struck the poor the most grievously, it took people of all sorts and conditions indiscriminately. ${ }^{9}$ It is precisely this trait that made plague so fearful, encouraging drastic measures to be taken. Despite the English regulations' remarkably egalitarian overtone and seemingly charitable resolutions, the early modern English idea of plague control was effectively reduced to a policy of isolation by virtue of providing the means for the confinement of the infected masses, taking almost no account of their health or well-being.

\footnotetext{
${ }^{5}$ Slack (1988) 435.

${ }^{6}$ Slack (1988) 436.

${ }^{7}$ Cf. Cohn (2010) 208-13.

${ }^{8}$ Paraphrased by John Graunt. Graunt (1662) 38.

${ }^{9}$ Hence, the playwright, Thomas Dekker, an eyewitness of the 1603 London plague wrote that 'Men, women, \& children dropt downe before him: houses were rifled, / streetes ransact, beautifull maidens throwne on their beds, and ravisht by / sicknes: rich mens Cofers broken open, and shared amongst prodigall heires / and vnthriftie seruants'. Dekker (1603).
} 


\section{PLAGUE EPIDEMIOLOGY AND MEDICINE IN EARLY MODERN ENGLAND}

Since the spread of the Black Death (1348-1349), ${ }^{10}$ plague was almost always, to some extent, present in the great cities like London, Bristol, or Norwich, causing morbidity and mortality. ${ }^{11}$ Severe outbreaks, considerably outnumbering the mortality rate of other diseases, such as smallpox, or fevers, were not particularly frequent. Nevertheless, plague was, by no means, confined to the cities and larger towns, but there were, based on the official bills of mortality, grossly 658,000 deaths from the bubonic plague between 1570 and 1670 in England as a whole, compared to the 225,000 deaths for London and its environs. ${ }^{12}$ These figures are, however, quite imprecise and unreliable. The keeping of the bills of mortality were themselves, according to the contemporary demographer, John Graunt (1620-1674), prompted by the major outbreaks, ${ }^{13}$ and plague related mortalities were oftentimes, due to the poor diagnoses, greatly underestimated. ${ }^{14}$ At any rate, it appears, there were six severe outbreaks in the period between 1563 and 1666, all affecting but also spreading outside of the confines of London. ${ }^{15}$

The first episode was the London plague of 1563 which, according to the Elizabethan historian, John Stow, was responsible for 17,404 deaths (approximately 15\% of London's total population then) in the city, followed by some poorly documented provincial outbreaks in 1563-1564. ${ }^{16}$ The second considerable visitation, apart from certain modest epidemics, ${ }^{17}$ ravished the country in 1592-1593. This outbreak claimed 15,003 Londoners' lives and of several more from Derby, Lichfield, Leicester, Shrewsbury, Nottingham, and Lincoln. ${ }^{18}$ The third episode started its rage in 1603, taking 30,561 lives in London out of its roughly 200,000 inhabitants, ${ }^{19}$ and lasted for eight years, causing several thousands more deaths in the years to follow. $^{20}$ The fourth took place in 1625 , taking according to Graunt's adjusted figures 46,000 Londoners' lives, with only 11 deaths in the preceding and 134 deaths in the following year. ${ }^{21}$

\footnotetext{
${ }^{10}$ For a brief overview of pandemics and epidemics see: Slack (2012) 17-34. Some argue, however, that based on the mortality rate and contemporaneous descriptions the Black Death ought not to be identified with the bubonic plague of later outbreaks. Cf. Theilmann and Cate (2007) 371-93.

${ }^{11}$ Gilman (2009) 130.

${ }^{12}$ Slack (1990b) 174.

${ }^{13}$ Graunt (1662) 3-4. Cf. Robertson (1996) 325-50.

${ }^{14}$ Graunt claims that approximately $1 / 4$ of plague related mortalities went unnoticed both in the plague-year of 1625 (a total of about 11,000 more deaths) and 1636 (at least 2,600 more deaths). Graunt (1662) 33.

${ }^{15}$ For a thorough overview consult Slack (1990b) 53-151.

${ }^{16}$ Creighton (1891) 304-309.

${ }^{17}$ Such as the Cambridge and Oxford plague of 1571, the Bristol plague of 1575, the Hull visitation of 1576, the London plague of 1578-1583, etc. See Creighton (1891) 337-51.

${ }^{18}$ Creighton (1891) 353, 357.

${ }^{19}$ I adhere to the figures provided by Graunt (1662) 31., which slightly differs from the annual bill of mortality for 1603 , indicating a total of 37,376 deaths for London, Westminster and their liberties with 32,368 deaths related to the plague. Cf. Chettle (1603).

${ }^{20}$ Graunt (1662) 33. In Bristol the death toll was approximately 3,000 compared to its population of about 20,000. In Norwich it was around 1,500 for about 17,000 city-dwellers. See Creighton (1891) 496-99.

${ }^{21}$ Graunt (1662) 33. For figures drawn from the provinces see Creighton (1891) 520-26.
} 
The fifth outbreak began in 1636, being responsible for approximately 13,000 deaths, and lasting for twelve years, in eight of which resulting in 2,000 more deaths. ${ }^{22}$ The Great Plague of London erupted in $1665,{ }^{23}$ with a death toll of at least 100,000 , compared to the city's population of approximately 350,000 , ceasing in the following year only with the city's utter destruction by the Great Fire.

It is not surprising therefore that medical, political and literary reflections ${ }^{24}$ on the epidemic grew steadily in early modern England. In the Middle Ages, a great number of Latin scholarly treatises and translations discussed, sometimes at length, the causes of and remedies for the dreaded disease. Arguably these treatises' most authoritative, but definitely most cited, sources were the works of Galen and Avicenna. Galen, a selection of whose 'works was for the first time used as the foundation for medical training curriculum' from the sixth century, ${ }^{25}$ describes in his $\Pi \varepsilon \rho \mathbf{i} \tau \tilde{\omega} \nu$ i $\delta \mathbf{i} \omega \nu \beta \iota \beta \lambda i \omega \nu$ (On my own books) the great Antonine Plague which broke out in the winter of $168-169,{ }^{26}$ while Avicenna reflects on the subject in his Canon medicinae (Canon of medicine) when he considers the diseases associated with the ill composition of ground waters and certain astrological correlations.

Thus, given these, mostly syncretic, treatises relied heavily on the classical authorities of ancient and medieval medicine, till the second half of the sixteenth century subsequent scholarly reflections on plague were predominantly governed by the Hippocratic and Galenic criteria of qualification on the one hand, and explanations by universal causes intrinsically deriving from Galen and Avicenna on the other hand. ${ }^{27}$ Physicians argued that in order to have a disease as true plague (vera peste) qualified, it had to fulfil the dual criteria of being both 'popular' and 'epidemic', that is, it 'had to spread over a vast region, killing all or most in that region regardless of age, social class, or other characteristics of a population. ${ }^{, 28}$ Furthermore, it also had to be a contagious disease stemming from natural and supernatural causes associated with, or manifesting in, above all, miasmatic air and pestiferous vapours. It is worth the noting however that in this period there was no 'clear-cut distinction between 'contagion' and 'infection". ${ }^{29}$ Contagion expressed, then, simply plague's virulent capacity of transmission. Girolamo Fracastoro in his 1546 treatise De contagione describes it as: 'quoeda ab vno in aliud transiens infectio, vel ipsum nomen ostendit', and so, it appears to him that contagion is virtually the same as infection (quapropter videtur contagio, consimilis quoedam infectio secundum substatiam). ${ }^{30}$

From the sixteenth century there was a marked change in medical plague literature which is well-exemplified by the appearance of a growing number of treatises in the vernacular, doubtless

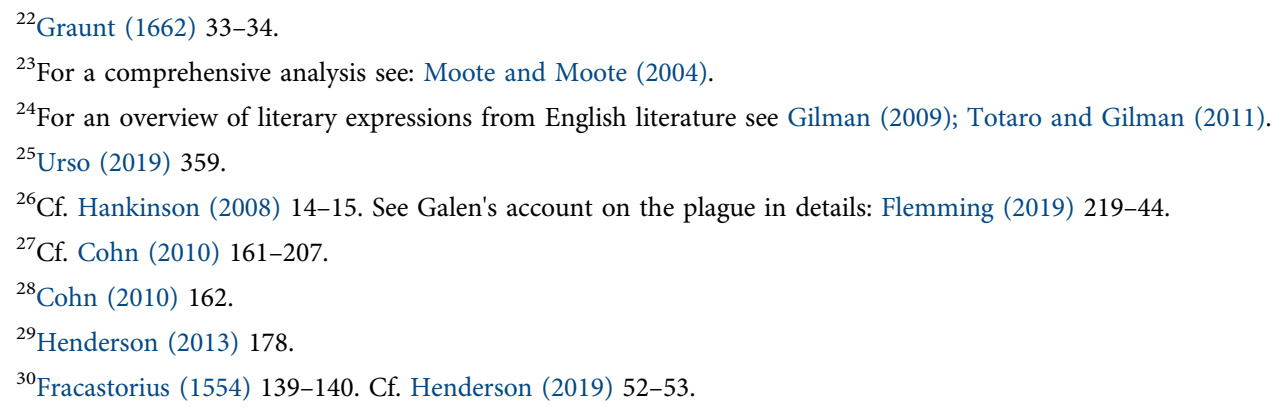


intended for the use of the educated laity. ${ }^{31}$ These novel approaches did not break with the Hippocratic and Galenic explanations altogether but late sixteenth-century treatises tended to lay considerable emphasise both on the observed correlation between plague and poverty ${ }^{32}$ and instructions for adequate government actions, something what might be considered 'the beginnings of a public health literature and a new consciousness of public health among physicians. ${ }^{33}$ Since plague was a global phenomenon, it is needless to say that the works of those Italian physicians who were the pioneers of these new trends held considerable sway in Elizabethan England as well. ${ }^{34}$

Still, in order to have a glimpse into the rationale and efficacy of early modern English plague controlling mechanisms, one ought to, first and foremost, have a fair understanding of both the well-tried contemporary European practices and the English physicians' respective knowledge of plague in general and these practices in particular. It is inevitable therefore to briefly consider plague control in those regions which might have influence on the English regulations, namely Northern France, the North Italian city-states, and Scotland, and those domestic medical sources which might disclose the progression of English medicine and plague epidemiology. Three sources belong to this latter group, the Advice of the Royal College of Physicians (1578), John Stockwood's translation of Johannes Ewich's De officio fidelis et prvdentis magistratvs (1583) and Thomas Lodge's A Treatise of Plague (1603). ${ }^{35}$

\section{THE ADVICE OF THE ROYAL COLLEGE OF PHYSICIANS (1578)}

The Royal College of Physicians set down its practical advices about how to avoid and treat plague from the second half of the sixteenth century. Their first advices appeared in print as an appendix to Queen Elizabeth's orders concerning the places infected with plague in $1578 .^{36}$ These advices were compiled on the Queen's express commands in order to provide an efficient and cheap remedy for all her subjects. For this reason, the ninth provision of the said order enjoined that a copy of the Physicians' Advice

nowe printed and sent with the sayd orders [...] may be fixed in market places, vpon places vsual for such publique matters, and in other townes in the bodies of the parishe churches, and chappells, in which aduise only such things are prescribed, as vsually are to be had and found in all countries without great charge or cost.

\footnotetext{
${ }^{31}$ Cf. Slack (1978) 237-271.; Keiser (2003) 292-324.

${ }^{32}$ Cohn (2010) 208-212.

${ }^{33}$ Cohn (2010) 248.

${ }^{34}$ Cf. Slack (1990b) 207-208.

${ }^{35}$ For present purposes I do not think that any detailed examination of either the Anonymous Good Councell against the plague (1592), or Simon Kellwaye's A Defensative against the Plague (1593) are warranted, since both are simple home manuals lacking any considerable novelty, though Kellwaye's treatise lists eleven brief advices for local magistrates. Kellwaye (1593) 13v-14r.

${ }^{36}$ 'An aduise set dovvne vpon her Maiesties expresse commandement, by the best learned in Physicke within this Realme' etc. in Orders, thought meete by her Maiestie, and her priuie Councell, to be executed throughout the counties of this realme, in such townes, villages, and other places, as are, or may be hereafter infected with the plague etc. (Christopher Barker 1578).
} 
Though the initial ideas for the plague regulations incorporated into the Elizabethan Book of Orders were drafted by the Queen's Italian court physician, Cesare Adelmare, ${ }^{37}$ the published version of the appended Physicians' Advice was rather 'trite and conservative. ${ }^{38}$ This piece did not provide any vulgar explanation for the causes of plague, or its definition, from its practical guidance, one may quite confidently infer, however, that the authors of the Advice endorsed the more traditional Galenic explanation for its origin, according to which plague arises from the mixture of corrupted moisture and air. ${ }^{39}$

Besides its popularity, the Advice's chief importance lies in its prolonged application. It was an appendix to the Book of Orders then was reinforced first in 1592 and 1593, then in 1603, and finally in 1625 . In the preface to the 1603 edition, one may even find an explanatory remark stating that James I,

hauing taken knowledge of certaine good orders that were vpon like occasion published in times past; together with certaine rules and Medicines prescribed' found 'both of them, to serue well for the present time

He thought fit to reissue both the Orders and the Advice verbatim, ${ }^{40}$ to be revised only under Charles I in $1630 .^{41}$

\section{JOHANNES EWICH'S THE DUETIE OF A FAITHFULL AND WISE MAGISTRATE (1583)}

The translator of the second piece, John Stockwood (c. 1546-1610), was an English clergyman and translator of Protestant scholarly literature who made a significant contribution to early modern English plague discourse by translating two Latin treatises, Théodore de Bèze's De peste quaestiones duae explicatae (1580) and Johannes Ewich's De officio fidelis et prvdentis magistratvs (1582). The first treatise did not carry much interest as it considered only two practical issues, namely whether plague is an infectious disease and whether Christians ought to withdraw from public interactions in time of an outbreak. Ewich's treatise is, on the other hand, a par excellence example of the pioneering novel approach of early modern medical scholarship and a worthy subject of distinguished attention. Its author, Johannes Ewich (1525-1588), ${ }^{42}$ was a German Protestant reformer and Bremen's renowned court physician who had vivid connections with contemporary Italian doctors. He studied medicine at the universities of Venice and

\footnotetext{
${ }^{37}$ Slack (1980) 7. Slack (1990b) 207-208.

${ }^{38}$ Slack (1990b) 209.

${ }^{39}$ Cf. Galen, Mixt. I. 530.

${ }^{40}$ Orders, thought meete by his Maiestie, and his Priuie Counsell, to be executed througout the counties of this realme etc. (Robert Baker 1603).

${ }^{41 ، A n}$ aduice set downe by the Colledge of Physitians, by His Maiesties speciall Command' etc. in Certaine Statvtes especially selected, and commanded by his Maiestie to be carefully put in execution by all Iustices, and other Officers of the Peace throughout the Realme etc. (Robert Barker 1630). Hammill (2010) 85, Slack (1980) 8-10, Slack (1990b) 217219.

${ }^{42}$ Aerztlichen Vereine zu Bremen (1844) 36-59.
} 
Padua and even witnessed first-hand a minor visitation of plague handled by the local magistrate at the latter location in 1556.

Though Ewich was a considerable authority on the subject, perhaps the greatest virtue of his treatise consists in its thorough eclecticism which allowed a display of only insignificant originality. This eclecticism is well portrayed, for example, by the treatise's lack of any proper definition of plague. Instead, in line with the most recent achievements of Italian medical scholarship, ${ }^{43}$ he rather distinguishes three kinds of plague according to their respective causes: 'alia enim mere diuina est, \& sic proprie appellari poßit; secunda naturalis: tertia contagiosa. ${ }^{44} \mathrm{He}$ argues that the first sort of plague 'riseth either immediately from God, or by the ordinance of God', being 'sent by the mere pleasure and wrath of God, being angrie with men for their sinnes. ${ }^{\text {'45 }}$ 'The naturall pestilence is that, which commeth of causes by meanes, and such as consist in nature. ${ }^{46}$ And finally, '[a]s for that plague, which hath his originall and beginning from infection' Ewich claims that 'the same is gotten either by companying or lying together, or by some disposition from the partie that is infected with it, and commeth through the meere negligence of men'. ${ }^{47}$ Nevertheless, he is apt to remind that 'albeit we vnderstand that euery plague is not the peculyar and proper punishment of GOD, nor yet alwayes immediatelye sent of God, [...] whatsoeuer originall and beginning it hath, alwayes and beefore all thinges, wee must flye vnto the helpe of GOD'; ${ }^{48}$ hence, the magistrates ought to, first and foremost, let the citizens turn 'earnestly \& vnfeignedly vnto God' by proclaiming and executing a public repentance. ${ }^{49}$

Given the almost all-encompassing Italian bent of his thought, it is not surprising that in respect of the envisioned and advised sanitary and administrative measures, Ewich's treatise dully follows the lead of the actual practice of some prominent Northern Italian city-states, and especially that of Padua. First, he recommends that a Board of Health, certain 'preseruers of health' (conseruatores sanitatis) to be appointed with a duty of taking away 'the publike and outwarde infection. ${ }^{, 50}$ Then, these said preservers of health should, in his opinion, see to the selection of well-trained and dutiful physicians, surgeons, and apothecaries. As a further measure of precaution, Ewich thinks that, due to the risk of contagion, larger gatherings of the body of citizens, such as 'publike asseblies, games, feastes, drinkings, marriages, daucings, fayers, schooles, churches, \& publike bathes', 'may be forbidden, or els seuered into diuers places and times. ${ }^{51}$ Nonetheless, as experience shows, these restrictions would surely stir up the unwanted wandering and begging of the poor 'from doore to doore', for which reason local magistrates ought to consider the possibility of either sending the poor 'some whither else, or to mainteine them by the common charge at their own houses so long, vntil $\mathrm{y}^{\mathrm{e}}$ sicknes

\footnotetext{
${ }^{43}$ Cf. Cohn (2010) 161-207.

${ }^{44}$ Evvich (1582) 13-14.

${ }^{45}$ Stockwood (1583) s.p.

${ }^{46}$ Stockwood (1583) s.p.

${ }^{47}$ Stockwood (1583) s.p.

${ }^{48}$ Stockwood (1583) 8r.

${ }^{49}$ Stockwood (1583) 8r-v.

${ }^{50}$ Stockwood (1583) $12 \mathrm{v}$.

${ }^{51}$ Stockwood (1583) 26v-27r.
} 
slack, that by this meanes occasion may bee taken from them of running vp \& downe, of receiuing, and scattering the infection. ${ }^{52}$ However, besides these and the like problems associated with the city's domestic poor, travellers and strangers coming from supposedly infected areas and dogs, cats, and other tamed animals wandering within the city walls were, for obvious reasons, also considered possible carriers of the disease. Ewich thought it wise therefore to let the preservers of health have warders at the gates appointed, commanding them not to receive any 'straunger, nor suffer any thinges to be brought in, vnlesse they haue some written testimonial, or sealed, being woorthie credite of not beeing counterfeit. ${ }^{53}$ Also, they shall, in his opinion, enact that domestic animals are to be kept at home, or they are to be either killed, or cast away. Finally, since infection and the spreading of plague is closely associated with miasma, Ewich suggests the introduction of a variety of sanitary measures from 'purging the ayre, of cleasing the streetes, of keeping away kine, hogges, and geese, the which doe greatly defile the same. ${ }^{54}$

However, if precaution and prevention fail, the magistrates ought to introduce provisional quarantine and organise the care for the afflicted. Thus, the infected houses ought to be 'noted and marked out by certaine signes \& tokes, as by setting of torches before $\mathrm{y}^{\mathrm{e}}$ doore' and the whole household ought to be 'charged, that they venture not to goe abroade vnto others, nor to receiue any vnto them, for the space of vi. or vii. weekes at the least'. ${ }^{55} \mathrm{Now}$, since members of a quarantined household were not allowed to make any contact with the outside world, depending on their financial and social standing, their respective daily provisions and adequate medical care were to be provided by the preserves of health.

\section{Thomas Lodge's A Treatise of the Plague (1603)}

The last contemporary source one ought to dully consider having the subject-matter in mind is Thomas Lodge's A Treatise of the Plague, ${ }^{56}$ published in London, in the Autumn of 1603. Although, from a strictly medical point of view, this treatise is also rather eclectic, and so on these grounds alone further qualified attention dedicated to it might well be objected, yet the person of its author and the implemented administrative advices make this piece remarkably fascinating. The author, Thomas Lodge (c. 1558-1625), ${ }^{57}$ was both a Lincoln's Inn trained lawyer and a Doctor of Medicine, educated at the prestigious Avignon University. Moreover, besides his legal training, he was also quite familiar with the operation of local government since his father, Sir Thomas Lodge, held several high positions in London, even serving a term in 1562 as Lord Mayor. ${ }^{58}$

\footnotetext{
${ }^{52}$ Stockwood (1583) 30r.

${ }^{53}$ Stockwood (1583) 51r.

${ }^{54}$ Stockwood (1583) 35v.

${ }^{55}$ Stockwood (1583) 53r-v.

${ }^{56}$ Lodge (1603).

${ }^{57}$ For a comprehensive biography see: Walker (1933) 410-432 and Walker (1934) 46-54.

${ }^{58}$ Walker (1933) 419-20.
} 
Lodge wrote his treatise with admittedly a lay public at sight, chiefly with the intent to discredit the popular practices of charlatans, capitalising on people's naivety. ${ }^{59}$ Though he earnestly believed that his books might 'be dispearsed among' all those families, without mentioning any restrictions whatsoever, that were 'visited, to the end they' might 'finde comfort and cure by their owne hands and diligence'. ${ }^{60}$ One should be rather cautious in delineating the exact scope of his targeted audience, and hence the intended meaning of the text. There are two crucial preliminary factors to be considered in this analysis: the social structure of early seventeenth-century households and the literacy rate of Stuart England. ${ }^{61}$

It should be kept in mind that perhaps the most characteristic aspect of Stuart society was its patriarchal superstructure. ${ }^{62}$ Arguably half of the population was living 'in households of six or more at any given time', and these 'households were almost invariably single-family units; that is, they included only one husband and wife, their offspring, and their servants. ${ }^{63}$ Thus, most seventeenth-century English families were the aggregates of both family members and servants united by the patriarchal head of the household. Concerning the literacy rate, '[p]reliminary research suggests that those who could do more than merely read and write their own names accounted for only about one-third of the population. ${ }^{64}$ It was, however, as might be expected, concentrated amongst the more prominent members of society; '[b]elow the level of the gentry, the degree of literacy probably varied with the actual need for it. ${ }^{\prime 65}$ It was surely higher amongst merchants, gunsmiths, drapers, and those craftsmen whose occupation brought them into contact with gentlemen. ${ }^{66}$ Thus, it appears Lodge's treatise was read mostly by the gentlemen and the more prosperous merchants and commoners, mainly those who could afford to keep a lodging in the countryside.

From a doctrinal point of view, the treatise is avowedly a syncretic work, subscribing to the Galenic tradition and, in particular, closely following François Vallériole's Traicté de la peste published in $1566 .{ }^{67}$ It is not surprising therefore that Lodge endorses an intrinsically Galenic definition of plague, describing it as 'a common and popular sicknesse, hapning in some region, or countrey, at a certaine time, caused by a certaine indisposition of the aire, or waters of the same region, producing in all sorts of people, one and the same kind of sicknesse; as namely burning Feuers, Tertian Agues, Opthalimes, or inflammation of the tunicle of the eies,

\footnotetext{
${ }^{59}$ 'There haue beene lately certaine Thessali that haue bestowed a new Printed liuery on euery olde post, and promised such myracles, as if they held the raine of desteny in their own hands, and were able to make old Aeson young againe: Amongst these, one by fortune is become my neighbour, who because at the first he vnderwrit not his billes, euery one that red them came flocking to me [...]' Lodge (1603).

${ }^{60}$ Lodge (1603).

${ }^{61}$ See Cressy (1977) 141-150.

${ }^{62}$ For a comprehensive analysis of seventeenth-century patriarchalism see: Schochet (1969) 413-44.

${ }^{63}$ Schochet (1969) 418. See a detailed overview in Laslett (1972) 125-58.

${ }^{64}$ Schochet (1969) 421.

${ }^{65}$ Schochet (1969) 421.

${ }^{66}$ Schochet (1969) 421.

${ }^{67}$ Roberts (1978) 89.
} 
Carbuncles, or Collicks, or general and gréeuous coughes, accompanied with shortnes of breath, or disenteries, or fluxes of blood'. ${ }^{68}$

He argues that plague has a twofold cause: its general cause consists in being 'a manifest signe of the wrath of God conceiued against us', ${ }^{69}$ while its efficient cause proceeds, according to him, 'from the venemous corruption of the humors and spirits of the body, infected by the attraction of corrupted aire, or infection of euil vapours, which haue the propertie to alter mans bodie, and poyson his spirits after a straunge and daungerous qualitie, contrary and mortall enemy to the vitall spirits, which haue their residence in the heart: by reason whereof it suddainly rauisheth \& shortly cutteth off mans life, who for the most part is attainted with such a venemous contagion'. 70

This twofold cause cries for a dual treatment, one spiritual the other corporal. The spiritual treatment, namely, recurse to God, clearly takes, in Lodge's opinion, precedence, ${ }^{71}$ while physical treatment is rather adjunctive, good only for the preservation or restoration of a good humoral balance. Nevertheless, being a contagious disease, plague could also be 'communicated vnto an other by touch, engendering one and the same disposition in him to whom it is communicated'. ${ }^{72}$ Plague control necessitates the implementation of certain administrative measures.

Lodge advises therefore that in case of an outbreak local authorities ought to, first and foremost, close their cities to all traffic coming from regions supposedly infected. However, persons of respect 'of whose prudence and securitie they may be assured' might be excepted, for 'it is not alwayes a consequent, that all the inhabitants of a Citty are alwayes infected, especially when they are men of respect, who haue the meanes, and obserue the methode to preserue themselues: whereof it is very necessary that the gouernours, and such as haue the kéeping of the gates, should haue respect: but for such as are vagabonds, masterlesse men, and of seruile and base condition, for such I say, they ought not to be admitted'. ${ }^{73}$

He also recommends that provided the local officials see any hope of containing the disease, once it reached the city, they shall, with a view to the 'common profit', conceal the fact from 'the common sorte' in order to avoid greater calamity. ${ }^{74}$ If, however, the epidemic spreads out, quarantining and sanitary regulations should form the local magistrates' chief concerns. It is vital that cities be 'kept cleane \& neat from al filth, dunghils and stinking rubbige that may bréed infection"75 and '[i]t is not amisse likewise at euery corner of the stréet, (at least twise in the wéek) to make cleare and quicke Bonefires to consume the malignant vapours of the ayre' ${ }^{76}$ Hence, casting out of any filth ought to be strictly forbidden and slaughterhouses ought not to 
continue their operation within the city walls. ${ }^{77}$ Finally, he recommends that 'certain discreet and skilful men in euery quarter and parish' ought to be charged with monitoring possible sicknesses with power of quarantining the affected and those who made any contact with them. ${ }^{78}$

What is the most interesting about the treatise's envisioned and advised administrative regulations is, however, their thorough and outspoken partiality, favouring the privileged classes of its subject audience. Despite the otherwise recommended isolation policies, Lodge emphasises that the 'first and chiefest remedie' is 'to change the place, flie farre and returne late' ${ }^{79}$ Being 'men of respect', 'knowing wel how to defend and preserue themselues by good remedies and dyet $^{\prime},{ }^{80}$ it was considered unlikely that they might carry the plague, and hence there seemed to be no reason to limit their movement. What is more, Lodge even adds, that if a person, proved to be infected with plague, fell sick in the house of such a person of respect, and this person 'had but small accesse vnto him, and the assistants that were with him,' were men of discretion, 'they ought not to be shut vp' for the whole of the otherwise allotted sixty-days period of time, but it should 'suffice in this case to keep them close some twenty or foure and twentie days, or somewhat longer.'

\section{SIXTEENTH-CENTURY FRENCH, ITALIAN, AND SCOTIISH POLICIES OF PLAGUE CONTROL}

Plague legislation originates with the Italian episode of the Black Death, going back to 1348, 'the famous Ordinances of Pistoia, and can be found soon afterwards in Mantua, Venice, Milan, Pavia, and other cities in northern Italy as well as in Spain and France. ${ }^{81}$ In line with the Hippocratic and Galenic paradigm, these ordinances focused mostly on the quality of the air 'and consequently hinged upon measures to restrict the presence of animals within cities, to remove open sewers and to clean streets. ${ }^{82}$ Hence, by the sixteenth century, there was a wide range of sanitary regulations enacted in most French and Italian towns.

In Northern France, '[r]efuse removal was initially organised on a parish level, with municipal councils directing their sergeants to ensure that townspeople cleaned both the front of their house and the street outside. ${ }^{83}$ 'Urination in public was first prohibited at Abbeville during the plague outbreak of 1457-9', and in Rouen during the plague of 1518 'the council had ruled that any house without a latrine now had to acquire one. ${ }^{84}$ In Italy, special ad hoc sanitary commissions of prominent citizens were erected to oversee that '[s]treets were to be cleaned,

\footnotetext{
${ }^{77}$ Lodge (1603) Ch. VIII. fol. 34.

${ }^{78}$ Lodge (1603) Ch. VIII. fol. 35.

${ }^{79}$ Lodge (1603) Ch. IIII. fol. 13.

${ }^{80}$ Lodge (1603) Ch. VIII. fol. 37.

${ }^{81}$ Cohn (2010) 202.

${ }^{82}$ Crawshaw (2013) 162

${ }^{83}$ Murphy (2013) 142.

${ }^{84}$ Murphy (2013) 142.
} 
garbage collected, sewers emptied, and the sale of meat and fruits strictly regulated. ${ }^{85}$ It was also common in times of an outbreak to severely restrict the operation of seemingly unsanitary but within normal circumstances unmolested trades, such as wool industry, or pig farming, within the city walls. Special regulations for inns, bath houses and brothels and ban on public processions and games were also frequent.

In Italy, different methods of isolation and quarantine were widely accepted by the beginning of the fifteenth century. In Venice a hospital (lazaretti) for plague patients was established on a permanent basis in 1423 which was soon followed by other Italian cities like Padua (1437), or Brescia (1438). ${ }^{86}$ By the turn of the century, these quarantine institutions found their way to France, the German states, the Low Countries, and eventually to Scotland. However, unlike the Italian and French policies of quarantine, which gave precedence to confinement to lazarettis and pesthouses, the Scots rather leaned towards the introduction of provisional home quarantine for the afflicted city-dwellers and cordon sanitaire for infected ships and cargo. ${ }^{87}$

The other peculiarity of the Scottish regulation is its reluctance to associate plague with poverty. In the 1500s, the growing acceptance of ideas concerned with contagion meant that French and Italian towns started to take precautionary measures against the most obvious and 'principal vectors of the disease', the 'itinerant poor, who were seen by the social elite as the most likely carriers of pestilence'. ${ }^{8}$ In Scotland this association seems to be mostly lacking though, it was true that 'various burghs passed acts which could be construed in a similar light, but the measures appear concerned principally with removal on non-native vagrants rather than strict control of the existing urban poor. ${ }^{, 89}$ In Italy, on the other hand, particularly hash measures introduced from the time of the 1570 s pandemic. In most Northern Italian cities begging was outlawed, vagrants, and the poor of the surrounding countryside were often refused entry to cities. In some cases they were even cast out forcibly. ${ }^{90}$

\section{EARLY MODERN ENGLISH POLICIES OF PLAGUE CONTROL: 1578-1625}

Plague regulations in England began with a royal proclamation issued on the $13^{\text {th }}$ of January 1518. 'In comparison with Italy or France', England was, thus, 'in this respect a benighted, backward country, as anxious foreign visitors often remarked. ${ }^{, 1}$ However, by the second half of the sixteenth century the development of English medicine and the steady growth of foreign

\footnotetext{
${ }^{85}$ Carmichael (1983) 510.

${ }^{86}$ Crawshaw (2013) 162.

${ }^{87}$ For a detailed overview of the Scottish responses see Oram (2007) 13-39 and Mullett (1950) 435-56.

${ }^{88}$ Murphy (2013) 157.

${ }^{89}$ Oram (2007) 23.

${ }^{90}$ Cf. Cohn (2010) 223-27.

${ }^{91}$ Slack (1990b) 201.
} 
influence on domestic plague policy made the conditions ripe for reconsideration and the introduction of novel central regulations. After the devastating 1563 visitation, the Queen's Italian physician, Cesare Adelmare, prepared a draft of suggested policies which was to a great extent modelled after the contemporary practices of some Northern Italian cities. ${ }^{92}$ Central to his proposition was the erection of powerful, Italian-styled boards of health, a body intrinsically foreign and antagonistic to the English common law tradition. Nevertheless, based on Continental ideals, a new Book of Orders was, after all, issued in 1578 to prompt an effective and centralised response for the emerging plague problem.

These Elizabethan orders listed a total number of seventeen provisions, nine of which settled chiefly administrative matters, such as the procedure, competence, and jurisdiction of local magistrates, three introduced sanitary regulations related to the burial of the dead and handling of infected items, two concerned quarantining and care for persons quarantined, and three dealt with various issues like taxation or freedom of expression. Its fourteenth provision enjoined, however, that 'the said Iustices may put in execution any other orders that by them at their generall assemblie shall be deuised and thought meet, tending to the preservation of her Maiesties subiectes from the infection, and to the end their care and diligence may the better appeare'. It also empowered the local authorities to presently imprison anyone who would 'wilfully breake and contemne' their orders, or, if the gravity of offence demanded a more severe reprobation, they could subject the offender to criminal procedure as well.

Considering it took the royal government until the late sixteenth century to include quarantine and isolation in its books of orders related to plague control ${ }^{93}$ and despite isolation policies, mostly for lepers, had been implemented throughout Europe, long before the Black Death, the Elizabethan quarantine regulations were to be deemed quite progressive in their time. Following the traditional pattern, ${ }^{94}$ it enforced six weeks of isolation for all the residents living in a household infected with plague. In cities and towns, this rule entailed that infected houses were 'to be closed vp on all parts during the time of restraint', yet if the infection took place in villages or hamlets, where the infected houses were separated from other houses, it allowed the residents to leave their houses and continue with their rural activities, provided they would not resort into companie of others, either publiquely or priuately during the said time of restraint'. Furthermore, they were required to 'weare some marke in their vppermost garments, or beare white rods in their hands at such time as they' would 'goe abroade'. If, however, any doubt arose that 'the masters and owners of the houses infected' would 'not duely obserue the directions of shutting vp their doores, specially in the night,' then sworn watchmen were to be appointed to 'attend and watch the house, and to apprehend any person' coming 'out of the house contrary to order'. Nevertheless, in cities and towns, the quarantined had to be provided for, and so the seventh provision set down that 'certaine persons dwelling within the townes infected' were 'to prouide and deliuer all necessaries of victuals' for the infected, but these persons were also strictly forbidden 'to resort to any publique assemblie during the tyme of such their attendance, as also to weare some marke on their vpper garment, or to beare a white rod in their hande, to the ende others may auoyde their companie.'

\footnotetext{
${ }^{92}$ Slack (1990b) 207-208.

${ }^{93}$ Newman (2012) 809. Though there are records of early sixteenth-century applications as well. See: Roger (2019).

${ }^{94}$ Quarantine derives its meaning from the Italian quarantenaria, a period of fourty days. Newman (2012) 809.
} 
The Elizabethan Orders did not associate plague explicitly with poverty ${ }^{95}$ but beggars and vagrants were generally considered potential carriers of the disease. ${ }^{96}$ Social measures were, from time to time, taken to prevent the poor from wandering abroad. ${ }^{97}$ For this very reason, the Orders enjoined that in case of an outbreak local authorities might impose and levy taxes 'according to the necessitie of the cause' to be used for the relief of the poor. Its real merit consists in the recognition that though the supply of daily provisions might well cease the wandering of the poor but this relief alone could not solve the equally grave problem of reinfection from infected items. ${ }^{98}$ That is why, in agreement with the Physicians' Advise, the thirteenth provision allowed that the levied money could be turned for compensating the damages caused by the burning of personal items as well, if the loss of such item might 'be greater then the poore estate of the owners of the same' might 'well beare', this way encouraging the poor to get rid of their infected belongings.

Despite its merits the Elizabethan Orders had, nevertheless, three major shortcomings crying for amendment.

First and foremost, the Orders rested solely on the royal prerogative, and so its taxes were imposed without the Parliament's consent. Second, the Orders failed to describe the power and competence of watchmen, charged with keeping the infected in awe and at their homes. And third, though in principle the Orders enjoined universal application, in practice, the Privy Council accepted from the beginning that a distinct book of orders is needed for the metropolitan city. ${ }^{99}$ Thus, after much debate, the City of London eventually issued its Orders to be set down of the Lord Mayor for repressing of disorders in 1583, and apart from minor changes, its provisions were consistently applied throughout the period. ${ }^{100}$

The London Orders, when compared to the Elizabethan Orders, are characterised by three marked differences.

First, its quarantine provisions are much more lenient as it enjoined only four weeks of confinement and one member of each quarantined households was allowed to go abroad for 'prouision of necessaries for the said family.' Second, the financial background for the relating expenses were covered on parish level. And finally, the London Orders incorporated a much wider range of sanitary regulations, such as the cleaning of streets and removing of waste, a general prohibition on keeping stray dogs, or amendment of the 'pauements where any holes be wherein any water or filth may stand to increase corruption and infection.'

\footnotetext{
${ }^{95}$ The 1604 statute is, on the other hand, perfectly explicit on the subject: towns 'found to be unable to relieve the poorer sort of such people so infected, who of necessity must be by some charitable course provided for, lest they should wander abroad and thereby infect others [...]' 2 Jac. 1 c. 31 in Pickering (1763) 141.

${ }^{96}$ Miller (2017) 49.

${ }^{97}$ For a general overview of Tudor poor laws see: Slack (1990a).

${ }^{98}$ Thomas Lodge, paraphrasing Alexander Benedictus, mentions an instance when a 'featherbed of one that was sicke of the plague in Venice [...] kept the venome seauen yeares, \& the first $y^{t}$ slept vpon the same at the end of the same terme were sodainly surprised with the plague'. Lodge (1603) Ch. VIII. fol. 39.

${ }^{99}$ Slack (1990b) 213.

${ }^{100}$ Cf. Slack (1990b) 213-215.
} 
The Elizabethan Orders 'dictated policy from one end of the kingdom to the other' till May $1666,{ }^{101}$ but King James's ascension brought some changes to this policy. His succession coincided with the worst outbreak so far and fast and drastic measures were required. Relying perhaps on his Scottish experiences in plague control, on the $23^{\text {rd }}$ of June 1603, as his first action, he ordered that courts sitting in London and Westminster, namely the King's Bench, Court of Common Pleas, Exchequer, Star Chamber, Court of Wards, and Requests, should process only such suits which might be performed in the absence of the parties, allowing 'the people of all sorts, and out of all parts of this Realme' to return to their homes, hoping that this way 'the said infection shalbe stayed'. ${ }^{102}$ Then, on the $30^{\text {th }}$ of June 1603 , being unable to convene the Parliament, he thought fit to reinforce the Elizabethan Book of Orders and the appended Advice. ${ }^{103}$ When the Blessed Parliament could, at last, assemble in 1604, it issued an act for the charitable relief and ordering of persons infected with the plague (2 Jac. 1 c. 31) to amend the two above noted shortcomings of the Elizabethan Orders, ${ }^{104}$ arguably, in part, prompted by James I. ${ }^{105}$

The first five provisions of this act virtually expounded the Orders' otherwise brief rules on taxation, enacting that in the first place the infected settlement had to provide for their poor. If, however, the local community was found unable to do so, the inhabitants living within five miles from the settlement afflicted might be ordered to contribute to the common costs. Provision number VII settled the power and procedure of watchmen, excepting them from liability of impeachment in case they had to resort to violence in enforcing the quarantining regulations. It also introduced criminal penalty for those who contrary to orders 'wilfully and contemptuously' went abroad. The gravity of the offence and hence of the inflicted penalty depended on the offender's apparent health conditions alone: those who had uncured infectious sores on them were to be 'deemed and adjudged as a felon, and to suffer pains of death', while those who did not have any sores on their bodies were to be punished merely as vagabonds. The eighth provision added, however, that 'no attainder of felony by virtue of this act shall extend to any attainder or corruption of the blood, or forfeiture of any goods, chattels, lands, tenements or hereditaments.' Finally, the ninth provision entrusted the Justices of Peace with an almost arbitrary power to issue any other such directions 'as unto them for the present necessity' should 'seem good in their discretion', though Church and school autonomies were, nevertheless, reinforced, empowering and authorising the vice-chancellors of Oxford and Cambridge, the bishops and deans of cathedral churches and the provost of Eton and warden of Winchester to wield and execute all the power described in the act and allotted to the local magistrates.

\footnotetext{
${ }^{101}$ Slack (1990b) 209.

${ }^{102}$ By the King forasmuch as the infection of the plague is at this present greatly increased and dispersed aswell in the cities of London and Westminster etc. (Robert Barker 1603).

${ }^{103}$ Orders, thought meete by his Maiestie, and his Priuie Counsell, to be executed throughout the counties of this realme etc. (Robert Barker 1603).

${ }^{104} 2$ Jac. 1 c. 31 . in Pickering (1763) 141-44.

${ }^{105}$ Slack (1990b) 211.
} 


\section{CONCLUSIONS}

There seems to be two hallmarks characterising early modern English policies of plague control: their outspoken and direct association of plague with poverty, and its indifference and elitist protectionism against the masses. The first trait seems to be nothing out of the ordinary, yet, given the lack of sanitary regulations and effective poor-relief, compared to the prevalent Continental practices, these measures were certainly uncharitable, and they were clearly not concerned with the health or well-being of the file and rank of ordinary Englishmen. Hence, apart from the above listed minor sanitary issues, these regulations are, in effect, reduced to an elitist policy of isolation, enforced by harsh punishments and a body of centralised Crown administrators. Though expressis verbis, the privileged classes of society did not enjoy any exception either under the provisions of the Orders or that of the 1604 statute, their liberty of movement between their distinct properties was, in fact, always, with minor restrictions, implied. They could, and, according to the contemporary records and testimonies, ${ }^{106}$ did, then, almost freely fly to the countryside or transfer sick members of the household from one house to another. Those who were not fortunate enough to own a second lodging were, however, either quarantined at their homes, or transferred to a pesthouse. In either case sick and well commingled which doubtless increased the death toll during an outbreak. ${ }^{107}$ Hence, it is not surprising that the Elizabethan and Jacobean quarantine-regulations came to be seen early as a dreadful punishment which disproportionally affected Stuart society. ${ }^{108}$

Popular sentiment is well portrayed by the contemporary clergymen, James Balmford (b. 1556), who wrote in A Short Dialogue concerning the Plagues Infection (1603) that the poorer sort [...] thinke it most extreame crueltie, to be barred from going abroad to seeke reliefe or maintenance for them and theirs, except they either had sufficient of their owne, or their wants were supplied. ${ }^{109}$ Yet, even people 'not so poore', ordered to 'kéepe their houses at their owne charges, till they be cleansed [...] think it an hell to be so long shut vp from companie and their businesse: the neglecting whereof is the decay of their state. ${ }^{110}$ This general resentment and despair lead, according to Balmford's report, to all sorts of wickedness and contempt of authority, making people disregard even the basic sanitary regulations. 'This peruerse course of too too many, in doing that which authority forbiddeth, and despising that which authoritie commandeth, to wit, fasting and praier, occasioneth me to obserue a notable proportion betwéene $\mathrm{y}^{\mathrm{e}}$ plague \& the wickednes of this time: by which proportion, God séemeth to teach men to say in their hearts, we would not be ruled, neither by reason nor authority, therefore are so many, as it were distracted in their sicknesse, and by no meanes to be ruled: so that some leape out of the windowes, and some runne into $\mathrm{y}^{\mathrm{e}}$ Thames.'

\footnotetext{
${ }^{106}$ See e.g. Ben Johnson's The Alchemist (1610). 'The Sicknesse hot, A Master quit, for feare, / His House in Towne: and left one Seruant there.'

${ }^{107}$ Newman (2012) 812.

${ }^{108}$ Gilman (2009) 155. See a detailed analysis on the public opinion concerning the 1636 quarantine-regulations in: Newman (2012) 826-88. For an early (1665) critique see: The shutting up infected houses as it is practised in England soberly debated By way of address from the poor souls that are visited, to their brethren that are free (s.n. 1665).

${ }^{109}$ Balmford (1603) 9.

${ }^{110}$ Balmford (1603) 9-10.
} 
After all, it can be concluded that despite its otherwise prudent and cautious measures, the Elizabethan and Jacobean regulation of plague control proved to be mostly ineffective for two interdependent causes: ill-suited policy, bringing popular resentment and contempt. Arguably, people were more afraid of the dire consequence of being shut up than plague itself. '[I]ndéed this impatiencie is', according to Balmford, 'the cause why so many smother the plague in themselues and their families, so long as they can to the hazarding of life'. ${ }^{11}$

\section{LITERATURE}

Aerztlichen Vereine zu Bremen, Biographische Skizzen verstorbener Bremisher Aerzte und Naturforscher (Johann Georg Heyse 1844).

Anon, Good Councell against the plague (Iohn Charlwood 1592).

Balmford, J., A Short Dialogue concerning the Plagues Infection (Richard Boyle 1603).

Bootsma, M. C. J. and Ferguson, N. M., 'The effect of public health measures on the 1918 influenza pandemic in U.S. cities' (2007) 104 Proceedings of the National Academy of Sciences 7588-93.

Carmichael, A. G., 'Plague Legislation in the Italian Renaissance' (1983) 57 Bulletin of the History of Medicine 508-25.

Chettle, H., A True bill of the whole number that hath died in the cittie of London, the citty of Westminster, the citty of Norwich etc (I. R. 1603).

Cohn, S. K., Cultures of Plague, Medical Thinking at the End of the Renaissance (Oxford University Press 2010).

Crawshaw, J. S., 'The Renaissance Invention of Quarantine' in L. Clark and C. Rawcliffe (eds.), The Fifteenth Century, Vol. XII: Society in an Age of Plague (The Boydell Press 2013) 161-74.

Creighton, C., A History of Epidemics in Britain, from A.D. 664 to the Extinction of Plague (Cambridge University Press 1891).

Cressy, D., 'Literacy in Seventeenth-Century England: More Evidence' (1977) 8 The Journal of Interdisciplinary History 141-50.

Dekker, T., The vvonderfull yeare. 1603 Wherein is shewed the picture of London, lying sicke of the plague (Thomas Creede 1603).

Evvich, I., De officio fidelis et prvdentis magistratvs tempore pestilentice Rempub. a contagion proseruandi liberandique Libri duo (Matthæus Harnisch 1582).

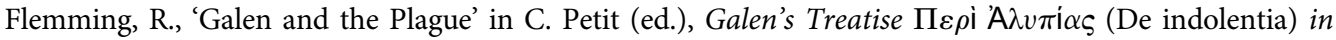
Context (Brill 2019) 219-244.

Fracastorius, H., De contagione et contagiosis morbis et eorum curatione (Apud Ioan. Tornaesium \& Guil. Gazeium 1554).

Gilman, E. B., Plague Writing in Early Modern England (University of Chicago Press 2009).

Graunt, J., Natural and Political Observations, Mentioned in a following Index, and made upon the Bills of Mortality ( $2^{\text {nd }}$ edn, Roycroft 1662).

Hammill, G., 'Miracles and Plagues: Plague Discourse as Political Thought' (2010) 10 Journal for Early Modern Cultural Studies, Rhetorics of Plague, Early and Late 85-104.

${ }^{111}$ Balmford (1603) 10. 
Hankinson, R. J., 'The man and his work' in R. J. Hankinson (ed.), The Cambridge Companion to Galen (Cambridge University Press 2008) 1-33.

Henderson, J. 'Coping with Epidemics in Renaissance Italy: Plague and the Great Pox' in L. Clark and C. Rawcliffe (eds.), The Fifteenth Century, Vol. XII: Society in an Age of Plague (The Boydell Press 2013) 175-94.

Henderson, J., Florence under Siege, Surviving Plague in an Early Modern City (Yale University Press 2019). Johnson, B., The alchemist (Thomas Snodham 1612).

Keiser, G. R., 'Two Medieval Plague Treatises and Their Afterlife in Early Modern England' (2003) 58 Journal of the History of Medicine and Allied Sciences 292-324.

Kellwaye, S., A Defensative against the Plague etc. (Iohn Windet 1593).

Laslett, P., 'Mean household size in England since the sixteenth century' in P. Laslett and R. Wall (eds.), Household and family in past time (Cambridge University Press 1972) 125-58.

Lodge, T., A treatise of the plague containing the nature, signes, and accidents of the same etc. (Edward White and N. L. 1603).

Miller, J., 'The Lives of the People' in J. Miller, Early Modern Britain, 1450-1750 (Cambridge University Press 2017) 30-61.

Moote, A. L. and Moote, D. C., The Great Plague. The Story of London's Most Deadly Year (Johns Hopkins University Press 2004).

Mullett, C. F., 'Plague Policy in Scotland, $16^{\text {th }}-17^{\text {th }}$ Centuries' (1950) 9 Osiris $435-56$.

Murphy, N., 'Plague Ordinances and the Management of Infectious Diseases in Northern French Towns, c. 1450-c. 1560' in L. Clark and C. Rawcliffe (eds.), The Fifteenth Century, Vol. XII: Society in an Age of Plague (The Boydell Press 2013) 139-60.

Newman, K. L. S., 'Shutt Up: Bubonic Plague and Quarantine in Early Modern England' (2012) 45 Journal of Social History, The Hidden History of Crime, Corruption, and States 809-34.

Oram, R. D., "It cannot be decernit quha are clean and quha are foulle.' Responses to Epidemic Disease in Sixteenth- and Seventeenth-Century Scotland' (2007) 30 Renaissance and Reformation/Renaissance et Réforme 13-39.

Pickering, D. (ed.), The Statues at Large, from the Thirty-ninth Year of Q. Elizabeth, to the Twelfth Year of K. Charles II. Inclusive. Vol. VII. (Joseph Bentham 1763).

Qazi, A., Qazi, J., Naseer, K., Zeeshan, M., Hardaker, G., Maitama, J. Z., Haruna, K., 'Analyzing Situational Awareness through Public Opinion to Predict Adoption of Social Distancing Amid Pandemic COVID19' (2020) Journal of Medical Virology https://onlinelibrary.wiley.com/doi/10.1002/jmv.25840.

Roberts, R. S., 'A note on Thomas Lodge's A treatise of the plague (1603)' (1978) 22 Medical History 89.

Robertson, J. C., 'Reckoning with London: interpreting the Bills of Mortality before John Graunt' (1996) 23 Urban History 325-350.

Roger, E. C., "To Be Shut Up': New Evidence for the Development of Quarantine Regulations in EarlyTudor England' (2019) Social History of Medicine https://doi.org/10.1093/shm/hkz031.

Schochet, G. J., 'Patriarchalism, Politics and Mass Attitudes in Stuart England' (1969) 12 The Historical Journal 413-441.

Slack, P., 'Book of Orders: The Making of English Social Policy, 1577-1631' (1980) 30 Transactions of the Royal Historical Society 1-22.

Slack, P., Plague, A Very Short Introduction (Oxford University Press 2012).

Slack, P., 'Mirrors of Health and Treasures of Poor Men: The Use of the Vernacular Medical Literature of Tudor England' in C. Webster (ed.), Health, Medicine and Morality in the Sixteenth Century (Cambridge University Press 1978) 237-71. 
Slack, P., 'Responses to Plague in Early Modern Europe: The Implications of Public Health' (1988) 55 Social Research 433-53.

Slack, P., The English Poor Laws 1531-1782 (Macmillan 1990a).

Slack, P., The Impact of Plague in Tudor and Stuart England (Clarendon Press 1990b).

Stockwood, J., The duetie of a faithfull and wise magistrate, in preseruing and deliuering of the eommon wealth etc. (Thomas Dawson 1583).

Theilmann, J. and Cate, F., 'A Plague of Plagues: The Problem of Plague Diagnosis in Medieval England' (2007) 37 The Journal of Interdisciplinary History 371-93.

Totaro, R. and Gilman, E. B. (eds.), Presenting the Plague in Early Modern England (Routledge 2011).

Urso, A. M., 'Translating Galen in the Medieval West: the Greek-Latin Translations' in P. Bouras-Vallianatos and B. Zipser (eds.), Brill's Companion to the Reception of Galen (Brill 2019) 359-80.

Walker, A., 'The Life of Thomas Lodge' (1933) 9 The Review of English Studies 410-32.

Walker, A., 'The Life of Thomas Lodge' (1934) 10 The Review of English Studies 46-54.

Open Access. This is an open-access article distributed under the terms of the Creative Commons Attribution 4.0 International License (https://creativecommons.org/licenses/by/4.0/), which permits unrestricted use, distribution, and reproduction in any medium, provided the original author and source are credited, a link to the CC License is provided, and changes - if any - are indicated. (SID_1) 